\title{
Potential of Self-reliant Lifestyle for a Single House in Housing Development Projects
}

\author{
Sirimas Hengrasmee, and Sant Chansomsak
}

\begin{abstract}
This paper is based on the research "The Study of Physical Potential of a Single House in Phitsanulok's Housing Development Projects for Supporting a Self-reliant Lifestyle" which surveyed and study the physical ability of single houses in Phitsanulok's housing development projects. Samples were taken mainly in the Amphor Muang district (urban district) of Phitsanulok province to evaluate self-reliant level of the housing majority. The self-reliance concept developed in the study is taken from the framework of the Philosophy of Sufficiency Economy and Sustainable Development. Investigations are focused on food (herbs, fruit, and vegetables), water, and energy. The results show that the majority of single houses in Phitsanulok have a high level of self-reliance. Most houses can produce about $100 \%$ of food requirement (herbs, fruit, and vegetables). Rainwater collection can be harvested for use up to $81 \%$ of water required for the out-of-house use. In energy category, the Low-user households $(6 \mathrm{kWh} /$ day $)$ can produce more than $100 \%$ of their electricity needed from the PVs on the rooftop. At least, about half of energy requirement can be produced for the intermediate-higher user $(18.5 \mathrm{kWh} / \mathrm{day})$. Moreover, a family practicing self-reliance can save up to 8,500 Baht/year.
\end{abstract}

Keywords- Housing Development; Self-reliance; Sustainable Development; Sufficiency Economy

\section{INTRODUCTION}

As living expense is generally rising in most countries, Thailand has also currently experienced similar circumstance. It is expected that more and more households would struggle from this situation very soon. Drawing from this ominous trend, the research aims to investigate the possibility of increasing self-reliant at a household level. The basis of this investigation is that being more independent would be of great benefit to a common household regarding their basic needs. Besides creating self-immunity to cope with situational changes in the near future, improvement of a self-reliant lifestyle, particularly at a family scale, also helps to reduce environmental impacts by lessening the Ecological Footprint created by the impacts of everyday's consumption [1, 2, 3, 4].

From previous studies [1, 5, 6, 7], a level of self-reliance is relevant to a way to utilise immediate resources and environments, though patterns of living and attempts to change are also crucial. The physical environments of a house and its land plot also influence the possibility for a family to be selfsufficient. Accordingly, this research places a focus on physical environments that provide a potential to produce basic needs, including food, water and energy.

\section{SCOPE AND OBJECTIVES OF THE RESEARCH}

The research focuses only on single houses in housing development projects in Phitsanulok, a province located in the northern part of Thailand. Similar to many cities, the development of Phitsanulok sprawls from the centre of the town to the area surrounding it. Selected housing development projects are chosen within approximately ten kilometers radius from the town centre. Since Phitsanulok being one of the major cities of the region, there are many new housing development projects being built especially during the past ten years. This study had selected over 100 projects with more than 250 different sample houses. During the study, there were a number of housing development projects currently under construction as well. However, only the projects that are over $80 \%$ of completion judging on the day of actual survey were counted in this research.

The primary objectives of the research are to study the ability of the existing single houses belonged to common housing development projects in Phitsanulok province to see whether it can support a more self-reliant lifestyle; and if it is so, to estimate the ability of achieving self-reliance by utilising immediate environment.

Housing development projects in Phitsanulok normally consist of several building types, single houses, twin houses, row houses, and shop houses. Some housing projects only built one type of building, but some involve several types. It is quite common for housing development to convert every available area into functional spaces. Therefore, most housing types are left with minimal open spaces. Among all the housing types, mostly only single house that may have unpaved open areas. As an open space is important in providing areas for food production, this research chose to initially focus on the single house, in order to study the possibility of self-reliance of the housing type that has more open areas compare to the others. It would give even more contribution to study further into other housing types as well.

Besides an open space, another element influences potential of self-reliance is the size and type of a roof. The size of the roof determines the ability to capture solar power and rainwater. The total roof area is used for the calculation of the amount of rainwater to be able to harvest by each household. For the energy estimation part, as Phitsanulok has the average number of solar radiation ranged between 15.8-22.3 MJ/m2day [8], it is a good opportunity for exploiting solar radiation by using photovoltaic (PV) cells for electricity generation. 
Since a type and orientation of the roof affects the capability of energy generation, only a southern side of the roof, the most solar efficient side of the roof, is used for this investigation. However, as an actual orientation of roofs is varied based on site contexts and land plots, the research assumes that all houses are properly oriented with the longitudinal axis on EastWest to reduce overall heat gain, and maximize the southern side of the roof. Based on the survey, the most popular types of roofs in Phitsanulok are gable and hipped roofs. The research thus infers that the capability of energy generation of a gable roof is $50 \%$ of the total roof area, while the solar harvest potential of the hipped roofs are $20 \%$ in a square shape hipped roof and $40 \%$ in a rectangular hipped roof.

\section{FRAMEWORK OF THE RESEARCH}

This research is taking a framework from the former study of an implementation of Philosophy of Sufficiency Economy and New Theory Agriculture, initiated by the present King of Thailand, into common single houses in suburban areas of Phitsanulok. However, this study focuses closer to the heart of the city by taking single houses of housing development projects surrounding the city centre to be the sample of the study. Sufficiency Economy and New Theory Agriculture has been used as a Thai version of sustainable development and is meant to serve as an underlying principle to all activities for a sustainable future. The main idea of Sufficiency Economy; to live with what one can have and not be extravagant, suggesting that when one only has what one should the sharing of resources is fairer, will greatly contribute to a sustainable future.

From the philosophy, the New Theory Agriculture is developed. The theory is aimed only for farmers, which selfreliance and contentment are the aim of the theory. The theory is divided in to three steps, from individual scale to wider community. The first step is based on producing enough products to be consumed in the family with some extra products to sell. This step is about the agricultural system, and encourages farmers to grow a diversity of plants to balance the ecological system and the needs of everyday life. The theory suggests farmers proportionally manage their land by divided it into the four parts of a rice field, a pond, a farm plants/crops part, and a part for housing and other necessary buildings. An approximate proportion was suggested, but the key is for the farmer to divide the land reasonably according to individual needs, ability and available labour.

The former study by Hengrasmee, S. [1] took the philosophy and the theory and adapted it to suburban community, where agriculture is not so common practice among the inhabitants. As the New Theory Agriculture suggests farmers live their life with less dependency on others for food and water, which represent basic rural needs, the suburban people are assumed to aim at increasing their selfreliant lifestyle in the areas of food (fruit and vegetables), water, and energy.

With the former study as a framework as well as the idea of self-reliance taking from the New Theory Agriculture, the research assumed that the ability to capture solar energy and rainwater should not be much different from the former ones.
However, an ability to produce food may be much lower than single houses in suburban areas.

\section{FINDINGS OF THE RESEARCH}

The ability to capture solar power and rainwater of a house is determined by the area of one's roof and the ability to grow food is from the open area, whether paved or unpaved. Therefore, the study has investigated the roof areas and open areas of selected houses. According to the survey, the most common land holding is between $200-300 \mathrm{~m}^{2}$, while the roof areas is between $100-150 \mathrm{~m}^{2}$, and the open spaces is between $50-150 \mathrm{~m}^{2}$ (Table I).

TABLE I. RESULTS OF THE SURVEY OF SINGLE HOUSES FROM SELECTED HOUSING DEVELOPMENT PROJECTS IN PHITSANULOK PROVINCE

\begin{tabular}{|c|c|c|c|}
\hline Items & Sizes & Samples & Percentages \\
\hline \multirow{4}{*}{$\begin{array}{l}\text { Land } \\
\text { Holdings }\end{array}$} & Smaller than $200 \mathrm{~m}^{2}$ & 48 & 18 \\
\hline & Between $200-300 \mathrm{~m}^{2}$ & 152 & 58 \\
\hline & Between $300-400 \mathrm{~m}^{2}$ & 46 & 18 \\
\hline & More than $400 \mathrm{~m}^{2}$ & 14 & 6 \\
\hline \multirow[t]{4}{*}{ Roof Areas } & Smaller than $100 \mathrm{~m}^{2}$ & 36 & 14 \\
\hline & Between $100-150 \mathrm{~m}^{2}$. & 144 & 55 \\
\hline & Between $150-200 \mathrm{~m}^{2}$ & 66 & 25 \\
\hline & More than $200 \mathrm{~m}^{2}$ & 14 & 6 \\
\hline \multirow{4}{*}{$\begin{array}{l}\text { Open } \\
\text { Spaces }\end{array}$} & Smaller than $50 \mathrm{~m}^{2}$ & 8 & 3 \\
\hline & Between $50-150 \mathrm{~m}^{2}$ & 200 & 77 \\
\hline & Between $150-250 \mathrm{~m}^{2}$. & 41 & 16 \\
\hline & More than $250 \mathrm{~m}^{2}$ & 11 & 4 \\
\hline
\end{tabular}

\section{A. Ability to Produce Food}

It is a fact that food is a necessity for human life. However, the understanding of where food comes from and the impacts of such process are not equally known to all people. Rural people, whose life involve in the process of food production, therefore are more connected to natural environment, while urban people are generally disconnected and commonly stick to just being consumers. Growing food in one's garden may indirectly reconnect urban people to the natural world. Nevertheless, the direct benefit of household food production is fresh food and lower living expenses.

The estimation on food consumption is made based on the national statistics of about four people/household [9]. Only fruit, vegetables, and herbs are considered as appropriate for food production in the selected single houses. Therefore, the amount of consumption per household is only estimated for those plants. Following the Dietary Reference Intake for Thai people [10] and suggestion on fruit and vegetables intake by FAO and WHO [11], a family would need $640 \mathrm{~g} /$ day of vegetables and $960 \mathrm{~g} / \mathrm{day}$ for fruit. Matching the area required for food production from some fruit (aiming at the ones that can bear fruit all year round), vegetables, and common herbs for yearly consumption, the total area requirement of $88.5 \mathrm{~m}^{2}$ is 
needed for fruit production, while $25-42 \mathrm{~m}^{2}$ is for vegetables, and $19.5 \mathrm{~m}^{2}$ is for herbs. Therefore, the research shows that most houses can produce their own food. The houses with open space ranged from more than $50 \mathrm{~m}^{2}$ up to $150 \mathrm{~m}^{2}$ are able to be as high as $100 \%$ self-reliance in food category, which represents about $77 \%$ of the housing samples.

\section{B. Ability to Harvest and Collect Water}

Water supply in urban area is generally accessible for all city dwellers. Therefore, it may not be seen as necessary for a family to collect rainwater for their use. However, the impact of hardscape and pavement as well as the unwanted rainwater from urban rooftop are the main causes of the overflow drainage system. Moreover, the cost of water supply will be inevitably rising in the near future, because clean water is getting scarce. Rainwater harvesting could therefore reduce the use of centrally water supply. Since it may not necessary to totally substitute reticulated water for rainwater in urban area, rainwater can use for watering the garden instead. Unlike uses in human, plants and out-of-house cleaning do not need portable quality water. So, rainwater would be the best substitute to reticulated water for that matter. An average Thai person uses about 200 litres of water each day. According to water consumption breakdown [12], the total of 25,550 1/year is estimated for the outside use of water from each household. Accordingly, the house with smallest roof area can harvest up to $50 \%$ of water requirement when the average rainfall of Phitsanulok is $1,375 \mathrm{~mm} /$ year (see Table II).

\section{Ability to Produce Energy}

Energy production from solar radiation via photovoltaic cells installed on top of the roof of each house is the option chosen for this investigation. Area and shape of the roof is vital to the amount of production as stated earlier. Energy requirement from a household is estimated from a survey of ownerships of household appliances for energy consumption done by the National Statistical Office [13, 14, 15, 16, 17]. According to the estimation, two scenarios of energy consumptions can be pointed out as low user $(6 \mathrm{kWh} /$ day $)$ and intermediate-higher user $(18.5 \mathrm{kWh} /$ day $)$. Former studies of Electricity Generation Authority of Thailand [18, 19] which installed several types of PVs had given the details about PV nominal power and installation area in square meters. Gridconnected system is used as model in this study, since standalone is not seen as necessary in urban areas. According to the average results taken from the former projects conducted by Electricity Generation Authority of Thailand, the amorphous silicon PV panels need more area than the crystalline ones. On average, a crystalline PV panel needs around $9 \mathrm{~m}^{2} / 1 \mathrm{~kW}$, while an amorphous silicon PV panel needs around $15 \mathrm{~m}^{2} / 1 \mathrm{~kW}_{\mathrm{p}}$. Therefore, the ability for energy production of each scenario against each type of PV and the area available for installation can be seen in Table II. The low user can easily produce electricity to their needs regardless of the PV types, while intermediate and higher user can produce at least $50 \%$ of the required electricity.

TABLE II. CAPACITY OF SELF-RELIANCE FOR SINGLE HOUSES IN HOUSING DEVELOPMENT PROJECTS

\begin{tabular}{|c|c|c|c|c|c|c|c|c|c|c|c|c|}
\hline \multicolumn{13}{|c|}{ Capacity for food production (herbs, fruit, vegetables) } \\
\hline Open spaces & \multicolumn{3}{|l|}{$<50 \mathrm{~m}^{2}$} & \multicolumn{3}{|c|}{$<150 \mathrm{~m}^{2}$} & \multicolumn{4}{|c|}{$<250 \mathrm{~m}^{2}$} & \multicolumn{2}{|c|}{$>250 \mathrm{~m}^{2}$} \\
\hline Herbs $\left(19.5 \mathrm{~m}^{2}\right)$ & \multicolumn{3}{|c|}{$100 \%$} & \multicolumn{3}{|c|}{$100 \%$} & \multicolumn{4}{|c|}{$100 \%$} & \multicolumn{2}{|c|}{$100 \%$} \\
\hline Vegetables $\left(25-42 \mathrm{~m}^{2}\right)$ & \multicolumn{3}{|c|}{$73 \%$} & \multicolumn{3}{|c|}{$100 \%$} & \multicolumn{4}{|c|}{$100 \%$} & \multicolumn{2}{|c|}{$100 \%$} \\
\hline Fruit $\left(88.5 \mathrm{~m}^{2}\right)$ & \multicolumn{3}{|c|}{$0 \%$} & \multicolumn{3}{|c|}{$100 \%$} & \multicolumn{4}{|c|}{$100 \%$} & \multicolumn{2}{|c|}{$100 \%$} \\
\hline Overall capacity & \multicolumn{3}{|c|}{$58 \%$} & \multicolumn{3}{|c|}{$100 \%$} & \multicolumn{4}{|c|}{$167 \%$} & \multicolumn{2}{|c|}{$>167 \%$} \\
\hline \multicolumn{13}{|c|}{ Capacity of rainwater collection } \\
\hline Roof areas & & & $<100 \mathrm{~m}^{2}$ & \multicolumn{3}{|c|}{$<150 \mathrm{~m}^{2}$} & \multirow{2}{*}{\multicolumn{3}{|c|}{$<200 \mathrm{~m}^{2}$}} & \multicolumn{3}{|l|}{$>200 \mathrm{~m}^{2}$} \\
\hline $\begin{array}{l}\text { Out-of-house use } \\
\left(25.6 \mathrm{~m}^{3} / \text { year }\right)\end{array}$ & \multicolumn{3}{|c|}{$54 \%$} & \multicolumn{3}{|c|}{$81 \%$} & & & & \multicolumn{3}{|c|}{$>108 \%$} \\
\hline \multicolumn{13}{|c|}{ Capacity of energy generation form PVs } \\
\hline Roof areas & & & $<100 \mathrm{~m}^{2}$ & \multicolumn{3}{|c|}{$<150 \mathrm{~m}^{2}$} & & & $<200 \mathrm{~m}^{2}$ & \multicolumn{3}{|l|}{$>200 \mathrm{~m}^{2}$} \\
\hline \multirow{2}{*}{ Solar efficient areas } & \multicolumn{3}{|c|}{ Solar efficiency } & & ar effici & & & $\mathrm{r}$ effici & & & ar efficier & \\
\hline & $50 \%$ & $40 \%$ & $25 \%$ & $50 \%$ & $40 \%$ & $25 \%$ & $50 \%$ & $40 \%$ & $25 \%$ & $50 \%$ & $40 \%$ & $25 \%$ \\
\hline Low user $\left(1.7 \mathrm{~kW}_{\mathrm{p}}\right)$ & & & & & & & & & & & & \\
\hline $\begin{array}{l}\text {-Mono/Polycrystalline } \\
\left(45 \mathrm{~m}^{2}\right)\end{array}$ & $327 \%$ & $261 \%$ & $163 \%$ & $490 \%$ & $392 \%$ & $245 \%$ & $654 \%$ & $523 \%$ & $327 \%$ & $>654 \%$ & $>523 \%$ & $>327 \%$ \\
\hline $\begin{array}{l}\text {-Amorphous Silicon } \\
\left(75 \mathrm{~m}^{2}\right)\end{array}$ & $208 \%$ & $167 \%$ & $104 \%$ & $313 \%$ & $250 \%$ & $156 \%$ & $417 \%$ & $333 \%$ & $208 \%$ & $>417 \%$ & $>333 \%$ & $>208 \%$ \\
\hline Intermediate-higher $(5 \mathrm{~kW}$ & & & & & & & & & & & & \\
\hline $\begin{array}{l}\text {-Mono/Polycrystalline } \\
\left(45 \mathrm{~m}^{2}\right)\end{array}$ & $111 \%$ & $89 \%$ & $56 \%$ & $167 \%$ & $133 \%$ & $83 \%$ & $222 \%$ & $178 \%$ & $178 \%$ & $>222 \%$ & $>178 \%$ & $>111 \%$ \\
\hline $\begin{array}{l}\text {-Amorphous Silicon } \\
\left(75 \mathrm{~m}^{2}\right)\end{array}$ & $67 \%$ & $53 \%$ & $33 \%$ & $100 \%$ & $80 \%$ & $50 \%$ & $133 \%$ & $107 \%$ & $67 \%$ & $>133 \%$ & $>107 \%$ & $>67 \%$ \\
\hline
\end{tabular}




\section{CONCLUSION}

The study shows that a family lives in an existing single house of Phitsanulok's housing development projects have high potential of being self-reliant. The most common size which has an open area as well as a total roof area of about 150 $\mathrm{m}^{2}$ (77\% and $55 \%$ of the selected samples consecutively) has a great potential to be self-sufficient. This house can be totally self-reliant in food and energy production (low user), while able to harvest up to $80 \%$ of rainwater for yearly use.

Nevertheless, only to understand the potential of a house would not be enough to lessening the human impacts on the environment, but an involvement of a family is the most crucial development. Actions introduced by this paper require commitment and devotion to complete. Apart from the benefit on the environment, an economic approach can also be used for stronger persuasion for a household production. More selfreliant on food aspect can reduce the need of buying in food products and common ingredients. According to a report from National Statistical Office [9], over 85\% of living expense is from daily consumption (accounted for 14,843 Baht out of the total living expense of 17,299 Baht/month). A breakdown on food expense of a farmer, provided by BioThai Foundation [20], gives a rough estimation of about $9 \%$ on fruit, $6 \%$ on vegetables and $16 \%$ on other condiments. Therefore based on the data, this research assumed about $20 \%$ of the expense all together may account for fruit, vegetable, and herbs. Thus about 8,000 Baht can possibly be saved each year if some food products can be produced at home. Rainwater harvest can also help to reduce the cost of water supply by about 500 baht/year calculated by using the reticulated water cost estimation program available online provided by Provincial Waterworks Authority [21]. Unfortunately, the reduction in living expense regarding energy production is not yet obvious, because of the high price of PVs and a long period payback time. Nevertheless, in the long run, when energy price sores even higher, energy production may be considered as agreeable to more families

Nevertheless, in general circumstances, urban people may not yet attract to the idea of self-reliance. Since the locations of their houses are normally close to all facilities and services, people can buy all they need. It is quite understandable that being self-reliant will not yet pose as a major concern of the Thai family currently living in urban areas. Better practice of self-reliance in urban areas or other places will, however, support sustainable development in Thailand. Thus, a major change in attitude is required.

Being more self-reliant is not an easy task, trying to be selfreliant in one aspect may prove harder than another aspect depending on each family circumstance. For example, to increase the ability of collecting energy and water from the sun and rain would be mainly involving with investing more money on the technological side. Meanwhile, to produce some food from the garden would require additional time and energy from the members of the family as well. It is necessary to discuss here that being more self-reliant would be beneficial to the family as well as the environment in the long run, but it is not something that can be readily achieved.
This paper investigates the potential of existing single houses of the current housing development projects in Phitsanulok province. Therefore, it provides the average of the maximum potential that a family can work their way to the full capacity overtime. PV panels can be fully or just partially installed. Since PVs are still quite expensive, it is possible to plan the installation in phrases. Similarly, the roof will equally harvest rainwater each year, depending on its catchment area. So the installation of a big water tank aiming for collecting up to the full potential, or fitting smaller tanks until reaching the full potential are within the focus of this paper. Comparably, the finding of potential for food production in existing single houses only affirmed that each family has a high chance to be able to sustain their daily needs of fruit and vegetables. The process of achieving it may vary from family to family. A kitchen garden can be as small as growing in a container, or a more permanent as a raised bed, or even up to dedicated patch in the garden. Land availability as well as time and skills of the grower will be different, therefore staring small and working their way up in a manageable scale may be a wise decision to start from. This is also the major key suggested throughout the Philosophy of Sufficiency Economy and New Theory Agriculture. Growing food will directly link a person to the land, earth, and nature. It may consider as a way to unite a family by taking part in the job and earn the produce of their labor together. Hiring a gardener would be an alternative way to foolproof and ensure food production within a family. To manage it this way may also provide job opportunity for some people. Several houses within the same housing development project or close by may join in hiring a person to do their gardening and there could be an opportunity for food sharing in this way as well.

It is also necessary to point out that the design of a house is important for leading the life of self-reliance. Open areas are proven useful for food production as well as roof areas for energy and rainwater collection. The design of the roof may not affect the amount of rain harvest, but will definitely have the impact on electricity generation from solar radiation. The popular use of hipped roof in Thailand makes smaller solar efficient areas for the energy production. However, physical ability of a house is not the only drawback for lessening human impacts on the environment, but commitment and devotion of individual are at the heart of the promotion. 


\section{REFERENCES}

[1] S. Hengrasmee, Implementation of "Sufficiency Economy": A Study of Suburban Sustainable Community in Thailand, Unpublished PhD Thesis, The University of Auckland, New Zealand, 2009.

[2] S. Hengrasmee, "Suburban self-sufficient living: An implementation of the Philosophy of Sufficiency Economy," Nakhara: Journal of Environmental Design and Planning, vol. 8, 2012, pp. 59-72.

[3] S. Hengrasmee, "A study of suburban Thailand," In R. Vale and B. Vale (Eds.), Living within a Fair Share Ecological Footprint, Oxon: Routledge, 2013

[4] B. Vale and R. Vale, Time to Eat the Dog?: The Real Guide to Sustainable Living, Thames and Hudson, 2009.

[5] S. Hengrasmee and B. Vale, "The philosophy of Sufficiency Economy and its practical implementation in Thai suburban areas: A sustainable future," In K. Thanapet (Ed.), Proceeding of CDAST-2008: Intellectuals, Creativity and Innovation for Self-Sufficiency, Phitsanulok: Faculty of Architecture, Naresuan University, 2008a, pp. 245-260.

[6] S. Hengrasmee and B. Vale, "The philosophy of "Sufficiency Economy" and sustainable suburban sommunity development in Thailand," In G. Foliente et al. (Eds.), Proceeding of the 2008 World Sustainable Building Conference, vol. 2, pp. 1470-1477, 2008 b. (Produced primarily as a web-based product)

[7] S. Hengrasmee and B. Vale, "The environmentally friendly household: An alternative to the completely self-sufficient house," In Building Technology Division, Faculty of Architecture, Kasetsart University (Ed.), Conference Proceeding of iNTA-SEGA 2009: Building Innovation, Technology \& Tradition, 2009. (Produced primarily as a CD-based product)

[8] Regional Office of Energy Development and Promotion 9, Solar radiation, Retrieved 12 September 2007, from http://www.dede.go.th/ dede/index.php?id=428, n.d.

[9] NSO, Statistical Yearbook Thailand 2012, Bangkok: National Statistical Office, 2012.

[10] Nutrition Division, Dietary Reference Intake for Thais 2003 (3rd ed.), Bangkok: Express Transportation Organization of Thailand, 2003.

[11] FAO and WHO, Report of the Joint FAO/WHO Workshop on Fruit and Vegetables for Health (September, 2004: Kobe, Japan), Philippines: $\mathrm{FAO} / \mathrm{WHO}, 2004$.

[12] Manager Online, "Interesting facts about in-house water consumption," Retrieved 10 September 2005, from http://www. manager.co.th/asp$\mathrm{bin} / \mathrm{mgrView}$.asp?NewsID=4698880440591, 4 June 2003.

[13] NSO, Report of The 1996 Household Energy Consumption Survey, Bangkok: National Statistical Office, Office of The Prime Minister, 1996.

[14] NSO, Report of The 1998 Household Energy Consumption Survey, Bangkok: National Statistical Office, Office of The Prime Minister, 1998.

[15] NSO, Report of The 2000 Household Energy Consumption Survey, Bangkok: National Statistical Office, Ministry of Information and Communication Technology, 2000.

[16] NSO, Report of The 2002 Household Energy Consumption Survey, Bangkok: National Statistical Office, Ministry of Information and Communication Technology, 2002.
[17] NSO, Report of The 2004 Household Energy Consumption Survey, Bangkok: National Statistical Office, Ministry of Information and Communication Technology, 2004.

[18] EGAT, Demonstration Project for Electricity Generation from rooftop by Photovoltaic cells, Phase 1 (10 houses), Bangkok: Electric Generating Authority of Thailand, 1998.

[19] EGAT, Demonstration Project for Electricity Generation from rooftop by Photovoltaic cells, Phase 2 (50 houses), Bangkok: Electric Generating Authority of Thailand, 2004.

[20] BioThai Foundation, Food Insecurity and Thailand, Bangkok: BioThai, n.d.

[21] Provincial Waterworks Authority (Creator), Reticulated water cost estimation program [Online program], Retrieved 10 September 2005, from http://www.pwa.co.th/service/billing.php, 6 October 2011.

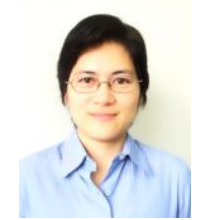

\section{Sirimas Hengrasmee}

Khonkaen, Thailand, 06/12/1975

B.Arch, Khonkaen University, Thailand, 1999

M.Arch (sustainable design), The University of Auckland, New Zealand, 2004 Ph.D. in Architecture, The University of Auckland, New Zealand, 2009.

Sirimas Hengrasmee is a full-time lecturer and the Director of Postgraduate Program at Faculty of Architecture, Naresuan University, Phitsanulok, Thailand. Her background of study is in the area of sustainability and the implementation of sustainable concepts to Thai contexts. Her current research is dealing with sustainable architecture, sustainable education, environmentally friendly practices, and behavioral changes.

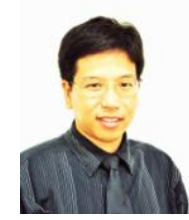

\section{Sant Chansomsak}

Bangkok, Thailand, 23/01/1975.

B.Arch, Chulalongkorn University, Thailand, 1998

M.Arch (sustainable design), The University of Auckland, New Zealand, 2004 Ph.D. in Architecture, The University of Auckland, New Zealand, 2009.

Sant Chansomsak is a full-time lecturer and currently appointed as Dean of the Faculty of Architecture, Naresuan University, Phitsanulok, Thailand. His research and articles are involved with sustainable architecture, sustainable school design and the roles of architects in sustainable community development. 